\title{
SKUTKI CYWILNE MAŁŻEŃSTWA WYZNANIOWEGO ZAWARTEGO PRZEZ OBYWATELI POLSKICH PRZED DUCHOWNYM KOŚCIOLA RZYMSKOKATOLICKIEGO ZA GRANICĄ
}

Treść: Wstęp. - 1. Zawarcie małżeństwa w prawie prywatnym międzynarodowym według zasady lex loci celebrationis matrimonii. - 2. Zawarcie małżeństwa w prawie prywatnym międzynarodowym według formy prawa ojczystego. - 2.1. Małżeństwo na obczyźnie a prawo wewnętrzne Kościoła katolickiego. - 2.2. Małżeństwo przed polskim duchownym za granicą a wymogi art. 8 k.r.o. - Podsumowanie.

\section{Wstęp}

Migracja Polaków za granicę jest zjawiskiem, które z różnych przyczyn i względów oraz z różnym natężeniem towarzyszy historii naszego kraju, zwłaszcza historii współczesnej. Przeobrażenia polityczne i gospodarczo-społeczne XX wieku a także otwarcie granic Europy stało się katalizatorem, który procesy migracyjne zintensyfikował w niespotykanej dotychczas skali. Według szacunkowych danych poza granicami Polski mieszka obecnie od 14 do 17 mln Polaków, głównie w Stanach Zjednoczonych (6-10 mln osób), Niemczech (ok. 1,5 mln), Brazylii (ok. $1 \mathrm{mln}$ ), Francji (ok. $1 \mathrm{mln}$ ), Kanadzie (ok. 600 tys.), Wielkiej Brytanii (ok. 150 tys.), Australii (130-180 tys.), Argentynie (100-170 tys. $)^{1}$, nie licząc tych, którzy wybierają emigrację sezonową związaną z popytem na zagranicznych rynkach pracy.

${ }^{1}$ Zob. Polacy za granica, [w:] Oficjalny portal promocyjny Rzeczpospolitej Polskiej http://www.poland.gov.pl/Polacy,za,granica,48.html. 
Mówiąc o emigracji nie sposób nie zauważyć, iż ruch migracyjny Polaków jest równocześnie w znacznej mierze ruchem migracyjnym osób deklarujących swoją przynależność do Kościoła rzymskokatolickiego. W kontekście tego faktu, zjawisko coraz częstszego pozostawania przez emigrantów w związkach nieformalnych lub niesakramentalnych budzić może uzasadnione zdumienie i troskę. Taki stan rzeczy jest wypadkową szeregu okoliczności, w tym również tych, które wpisują się w tendencję ogólną, mającą swe korzenie w nowej mentalności społecznej. Wydaje się jednakże, iż niebagatelne znaczenie w tej mierze odgrywa również brak świadomości prawnej (zarówno wiernych jak i duchowieństwa) co do tego, czy w ogóle możliwe jest zawarcie za granicą małżeństwa w formie wyznaniowej, które podlegałoby prawu polskiemu.

Udzielenie odpowiedzi na to pytanie nie jest zadaniem łatwym. Zagadnienie to dotyka bowiem styku trzech porządków prawnych: prawa prywatnego międzynarodowego ${ }^{2}$, prawa polskiego 3 oraz prawa kanonicznego ${ }^{4}$. Jest ono przy tym zagadnieniem niejako już ze swej natury wielopłaszczyznowym i polemicznym, stąd też przedmiotową analizę zawężono jedynie do przypadku zawarcia małżeństwa przez dwoje nupturientów wyznania rzymskokatolickiego, będących obywatelami polskimi. Poza rozważaniami pozostawiono natomiast małżeństwa mieszane (z uwagi na wyznanie lub obywatelstwo) a także kwestie dotyczące możliwości zawarcia wyznaniowego małżeństwa za granicą przez pełnomocnika.

Problematyka będąca przedmiotem niniejszej publikacji stanowi próbę odpowiedzi na pytania ważne - jak wydaje się - dla osób wiążących swe losy z obczyzną w dłuższej lub krótszej perspektywie ale również i dla tych, którzy chcieliby zawrzeć związek małżeński poza granicami kraju w trakcie np. zagranicznej pielgrzymki.

2 Ustawa z dnia 12 listopada 1965 r. Prawo prywatne międzynarodowe (Dz. U. z 1965, Nr 46, poz. 290 z późn. zm.), dalej jako p.p.m.

${ }^{3}$ Ustawa z dnia 25 lutego 1964 r. Kodeks rodzinny i opiekuńczy (Dz.U z 1964, Nr 9, poz.59 z późn. zm.), dalej jako k.r.o. Ustawa z dnia 29 listopada 1986 r. Prawo o aktach stanu cywilnego (Dz. U z 1986, Nr 36, poz. 180 z późn. zm.), dalej jako PrAsc.

${ }^{4}$ Kodeks Prawa Kanonicznego z 1983 r., dalej jako KPK. 


\section{Zawarcie malżeństwa $w$ prawie prywatnym międzynarodowym według zasady lex loci celebrationis matrimonii}

Zgodnie $\mathrm{z}$ art. $15 \S 1$ p.p.m forma zawarcia małżeństwa podlega prawu państwa, w którym jest ono zawierane. Wśród systemów prawnych spotkać można systemy uznające bądź to wyłącznie cywilną formę zawarcia małżeństwa (np. Francja, Niemcy, Austria, Belgia, Holandia, Luksemburg, Białoruś, Ukraina, Peru, Turcja, Chile), bądź to wyłącznie formę wyznaniową (np. Grecja, Hiszpania, Lichtenstein, Izrael, Irak, Quebeck) albo też takie, które uznają obie te formy za równorzędne i alternatywne (np. Włochy, Brazylia, Portugalia, Słowacja, Litwa, wspólnota brytyjska, państwa skandynawskie). Istnieją też systemy prawne uznające małżeństwa zawierane na podstawie samego konsensusu, bez udziału przedstawicieli władzy świeckiej lub kościelnej (np.Stan New York) ${ }^{5}$. Generalnie, małżeństwa w formie religijnej przewidują prawodawstwa m.in.: Australii, Brazylii, Danii, Dominikany, Etiopii, Filipin, Finlandii, Ghany, Grecji, Haitii, Hiszpanii, Hongkongu, Indii, Irlandii, Islandii, Izraela, Kanady, Kenii, Kolumbii, Kostaryki, Liberii, Malezji, Malty, Norwegii, Nowej Zelandii, Panamy, Peru, Polski, Portugalii, San Marino, Sri Lanki, Stanów Zjednoczonych Ameryki Północnej, Tanzanii, Wielkiej Brytanii i Włoch ${ }^{6}$.

Mówiąc o zasadzie lex loci celebrationis podkreślić należy, iż art. $1 \S 2$ p.p.m. statuuje regułę, w myśl której przepisów p.p.m nie stosuje się, jeżeli umowa międzynarodowa, której Polska jest strona, postanawia inaczej. A zatem, aby ustalić, czy zasada lex loci celebrationis ma zastosowanie w danym kraju należy ustalić, czy nie została ona ograniczona lub zniesiona w wiążącej Polskę umowie dwustronnej. Polska podpisała dwustronne umowy międzynarodowe zawierające przepisy kolizyjne w zakresie zawarcia formy małżeństwa z następującymi państwami: Austrią ${ }^{7}$ Białorusią ${ }^{8}$ Bułgarią ${ }^{9}$, Czechosłowacja ${ }^{10}$, Estonią ${ }^{11}$,

\footnotetext{
5 W. LudwiczaK, Międzynarodowe prawo prywatne, Warszawa 1979, s. 161.

${ }^{6}$ R. Sobański, Sens polskiego konkordatu, Państwo i Prawo 1994, z. 7-8, s. 11.

7 Dz.U. z 1974, Nr 6, poz. 33 z późn. zm.

${ }^{8}$ Dz.U. z 1995, Nr 128, poz. 619.

9 Dz.U. z 1963, Nr 17, poz. 88 z późn. zm.

${ }^{10}$ Dz.U. z 1989, Nr 39, poz. 210 z późn. zm.

${ }^{11}$ Dz.U. z 2000, Nr 5, poz. 49.
} 
Finlandią ${ }^{12}$, Francją $^{13}$, Jugosławia ${ }^{14}$, Koreą Północną ${ }^{15}, \mathrm{Kubą}^{16}$, Litwą ${ }^{17}$, Łotwą $^{18}$, Mongolią ${ }^{19}$, Federacją Rosyjską ${ }^{20}$, Rumunią ${ }^{21}$, Ukrainą ${ }^{22}$, Węgrami $^{23}$, Wietnamem ${ }^{24}$.

Rozwiązania przewidziane w tych umowach co do zasady zbliżone są - jak zauważa się w piśmiennictwie ${ }^{25}$ - do wynikającej z art. 15 § 1 p.p.m zasady lex loci celebrationis

Uwagi powyższe prowadzą zatem do wniosku, że jeżeli obywatele polscy zawrą związek małżeński w formie wyznaniowej w jednym z państw, w którym forma wyznaniowa w odniesieniu do Kościoła katolickiego jest prawnie dopuszczalna, małżeństwo tak zawarte będzie wywoływało skutki w polskim porządku prawnym ${ }^{26}$. Nadmienić jednakże trzeba, iż nupturienci zawierający związek małżeński zgodnie z lex loci celebrationis winni spełnić wszelkie wymogi, jakie stawia miejscowe ustawodawstwo. Mogą to być wymogi pobytu, miejsca zamieszkania, zapowiedzi, braku sprzeciwu itp. czyli wszelkie warunki

${ }^{12}$ Dz.U. z 1981, Nr 27, poz. 140 z późn. zm.

${ }^{13}$ Dz.U. z 1969, Nr 4, poz. 22 z późn. zm.

${ }^{14}$ Dz.U. z 1963, Nr 27, poz.162 z późn. zm.

${ }^{15}$ Dz.U. z 1987, Nr 24, poz.135.

${ }^{16}$ Dz.U. z 1984, Nr 47, poz. 247.

${ }^{17}$ Dz.U. z 1994, Nr 35, poz. 130 z późn. zm.

${ }^{18}$ Dz.U. z 1995, Nr 110, poz. 534 z późn. zm.

${ }^{19}$ Dz.U. z 1972, Nr 36, poz. 244.

${ }^{20}$ Dz.U. z 2002, Nr 83, poz. 750.

${ }^{21}$ Dz.U. z 2002, Nr 83, poz. 752.

${ }^{22}$ Dz.U. z 1994, Nr 96, poz. 465 z późn. zm.

${ }^{23}$ Dz.U. z 1960, Nr 8, poz. 54 z późn. zm.

${ }^{24}$ Dz.U. z 1995, Nr 55, poz. 289. Wszystkie powyższe umowy podawane są za: K. Pietrzykowki, Komentarz do art. 1 k.r.o., w: Kodeks rodzinny i opiekuńczy. Komentarz, (red.) K. Pietrzykowski, Warszawa 2010, s. 130-131.

${ }^{25} \mathrm{~K}$. PIETRZYKowsKi, Międzynarodowe aspekty zawarcia matżeństwa wyznaniowego, w: Rozprawy prawnicze. Księga pamiątkowa Profesora Maksymiliana Pazdana, Kraków 2005, s. 274.

${ }^{26}$ Pogląd ten powszechnie przyjmowany jest w literaturze przedmiotu, zob. m.in. K. PietrZykowski, Zawarcie malzeństwa i przesłanki jego ważności w prawie międzynarodowym prywatnym, Warszawa 1985, s. 90-91; tenże, Komentarz do art. 1 k.r.o., w: Kodeks rodzinny i opiekuńczy ..., j.w., s. 136; J. STRZEBIŃczYK, Zawarcie matzeństwa wyznaniowego podlegajacego prawu polskiemu, Rejent 1999, nr 4, s. 38. 
wymagane przez prawo pozytywne obowiązujące w miejscu zawarcia, poza wymogami materialnymi ${ }^{27}$. Dla przykładu wskazać można, iż $\mathrm{w}$ prawie włoskim dla małżeństwa $\mathrm{w}$ formie wyznaniowej wymagane jest dokonanie m.in. zgłoszenia cywilnego zaś urzędnik stanu cywilnego wydaje zezwolenie z oznaczeniem osoby duchownego. Uroczystość zawarcia małżeństwa może nastąpić albo w gminie miejsca duchownego (który z uwagi na szczegółowe postanowienie wynikające z art. 21 ustawy nr 1159/1929 musi mieć obywatelstwo włoskie) albo w gminie miejsca pobytu zawierających małżeństwo albo w innej gminie jednakże takiej, która znajduje się na obszarze okręgu, w którym ten duchowny jest upoważniony do sprawowania funkcji. Małżeństwo zawarte $\mathrm{w}$ formie wyznaniowej podlega we Włoszech wpisowi do rejestru stanu cywilnego, na wniosek zgłoszony przez proboszcza ${ }^{28}$. W Wielkiej Brytanii wymagane jest m.in. ogłoszenie o małżeństwie. W Szkocji, niezależnie od formy małżeństwa, urzędnik stanu cywilnego obwieszcza nazwiska kandydatów na małżonków i datę zawarcia małżeństwa w urzędzie stanu cywilnego, w Anglii i Walii, w przypadku wyznań innych niż Kościół Anglii i Kościół Walii, urzędnik stanu cywilnego dokonuje wpisu informacji o kandydatach na małżonków do specjalnego spisu (Marriage Notice Book) i wywiesza ogłoszenie o małżeństwie. Małżeństwo nie może być zawarte przed upływem 15 dni po dokonaniu ogłoszeń ani po upływie 3 miesięcy w Szkocji oraz 12 miesięcy w Anglii i Walii. Po zakończeniu przedmiotowej procedury urzędnik stanu cywilnego wystawia stosowny dokument, który zaświadcza o dopełnieniu wszystkich wymogów wstępnych. Bez tego

${ }^{27}$ W. LudwiczaK, Międzynarodowe prawo ..., j.w., s. 162-163. Wymogi materiale określa art. 14 p.p.m., który stanowi, iż „o możności zawarcia małżeństwa rozstrzyga w stosunku do każdej ze stron jej prawo ojczyste”. Określenie przeszkód małżeńskich jak również rozróżnienie przesłanek formalnych i materialnych zależy od konkretnego systemu prawnego. Rozróżnienie to w praktyce bywa przedmiotem licznych kontrowersji (zob. K. Pietrzykowski, Zawarcie matżeństwa ..., j.w., s. 14-21).

${ }^{28} \mathrm{R}$. CALVIGNIONI, Zawarcie matżeństwa cywilnego w formie wyznaniowej $i$ uznanie dziecka we włoskim prawie rodzinnym, w: Prawo rodzinne w Polsce i w Europie, (red.) P. Kasprzyk, Lublin 2005, s. 363. 
zaświadczenia małżeństwo nie może być zawarte. Rejestrację małżeństw dokonanych przez uprawnionych duchownych przesyła się co trzy miesiące do tzw. Registral General ${ }^{29}$. W Hiszpanii urzędnik stanu cywilnego wydaje zaświadczenie o zdolności do zawarcia małżeństwa, jeżeli małżeństwo jest zawierane według wymogów religii żydowskiej i Kościoła ewangelickiego, zaś w przypadku małżeństw katolickich i islamskich ustalenie wymogów koniecznych do zawarcia małżeństwa następuje dopiero w chwili wpisu małżeństwa do rejestru stanu cywilnego ${ }^{30}$.

Zgodnie $\mathrm{z}$ art. 73 ust. 1 PrAsc akt stanu cywilnego sporządzony za granicą może być wpisany do polskich ksiąg stanu cywilnego na wniosek osoby zainteresowanej lub z urzędu. W doktrynie podkreśla się, iż prawo polskie nie przewiduje - co do zasady ${ }^{31}$ - obowiązku transkrypcji (wpisania) aktów zagranicznych dotyczących obywateli polskich. Transkrypcja nie jest zatem wymogiem skuteczności takiego zagranicznego aktu w polskim porządku prawnym ${ }^{32}$. Zaznaczyć jednakże należy, iż wpisowi podlegać może tylko taki akt, który w świetle przepisów prawa danego państwa obcego jest aktem stanu cywilnego, tzn. jest zapisem zdarzenia z zakresu małżeństwa, dokonanym przez organ państwowy lub inny, upoważniony do prowadzenia tej rejestracji przez prawo danego państwa ${ }^{33}$. Oznacza to, iż np. metryka sporządzona przez władze kościelne w państwie, które uznaje

${ }^{29}$ C. NAST, Zawarcie zwiazku matżeńskiego oraz problem uznania dziecka $w$ kilku państwach członkowskich Międzynarodowej Komisji Stanu Cywilnego, w: Prawo rodzinne ..., j.w., s. 325.

${ }^{30}$ Tamże, s. 327.

${ }^{31} \mathrm{Na}$ wyjątek od powyższej reguły wskazał m.in. Sąd Najwyższy w wyroku z 13 czerwca 2000 r. w sprawie III CKN 260/00 stwierdzając, iż nie można skutecznie żądać unieważnienia małżeństwa bez uprzedniej transkrypcji zagranicznego aktu stanu cywilnego, stwierdzającego zawarcie tego małżeństwa (OSNC 2000, nr 12, poz. 230).

${ }^{32}$ A. Czajkowska, Komentarz do art. 73 PrAsc, w: A. Czajkowska, E. Pachniewska, Prawo o aktach stanu cywilnego. Komentarz. Orzecznictwo. Wzory dokumentów i pism, Warszawa 2009, s. 216.

33 J. Litwin, Prawo o aktach stanu cywilnego. Komentarz, Warszawa 1961, s. 521. 
wyłącznie świecką formę rejestracji stanu cywilnego, nie może być transkrybowana w Polsce ${ }^{34}$.

Zawarcie związku małżeńskiego przed duchownym Kościoła katolickiego działającego poza granicami Rzeczpospolitej Polskiej, jakkolwiek wywołuje analogiczne skutki cywilne (przy spełnieniu wszystkich wskazanych wyżej przesłanek) jak małżeństwo zawarte $\mathrm{w}$ formie konkordatowej ${ }^{35}$ przed duchownym katolickim w Polsce, to jednakże nie może być z nim utożsamiane. Skutki cywilne małżeństwa wyznaniowego zawartego według lex loci celebrationis nie wynikają bowiem w tym przypadku z dyspozycji art. 1 § 2 i 3 k.r.o. lecz z przepisów prawa prywatnego międzynarodowego. To zaś, iż małżeństwo wyznaniowe zawarte za granicą według formy lokalnej nie jest tożsame z małżeństwem wyznaniowym o jakim mowa w art. 1 § 2 i 3 k.r.o. powoduje tę zasadniczą konsekwencję, iż skuteczność formy zawarcia małżeństwa ocenia się w oparciu o kryteria właściwe dla każdego z tych porządków, zaś niedochowanie przepisów dotyczących formy właściwej dla lex loci celebrationis (ani formy ojczystej - o czym niżej) rodzi takie skutki, jakie wynikają z przepisów prawa obowiązującego w miejscu zawarcia związku małżeńskiego ${ }^{36}$.

Omawiając przedmiotowe zagadnienie podkreślić również należy, iż fakt zawarcia małżeństwa przed duchownym katolickim mającym obywatelstwo polskie jednakże inkardynowanym w diecezji na obszarze innego państwa, nie czyni tak zawartego małżeństwa, „małżeństwem zawartym w obecności duchownego" w rozumieniu art. 1 $\S 2$ i 3 k.r.o. Przepisy polskiego prawa rodzinnego regulując kwestię zawarcia małżeństwa $\mathrm{w}$ formie przewidzianej prawem wewnętrznym danego kościoła lub związku wyznaniowego odnoszą się bowiem do tych kościołów lub związków wyznaniowych, które - ujmując rzecz w skrócie - „działaja” na obszarze Rzeczpospolitej Polskiej. Regulują zatem kwestię zawarcia związku małżeńskiego jedynie przed tymi

\footnotetext{
${ }^{34}$ A. Czajkowska, Komentarz ..., j.w., s. 218.

${ }^{35}$ Terminu tego używa A. MĄCZYŃSKI (Konkordatowa forma zawarcia malżeństwa, Rejent 2003, nr 10, s. 138).

${ }^{36}$ W. LudwiczaK, Międzynarodowe prawo ..., j.w., s. 162.
} 
osobami duchownymi, które wchodzą w skład struktury organizacyjnej Kościoła katolickiego w Polsce. O przynależności natomiast danego duchownego do określonego kościoła partykularnego nie decyduje jego obywatelstwo ani miejsce pełnienia faktycznej posługi lecz - zgodnie z przepisami prawa kanonicznego ${ }^{37}$ - akt inkardynacji ${ }^{38}$. Obrazując powyższą tezę konkretnym przykładem wskazać można, iż małżeństwo zawarte w Polsce przed inkardynowanym w polskiej diecezji księdzem np. z Filipin będzie (po spełnieniu wymogów z art. $1 \S 2$ i 3 oraz 8 k.r.o.) małżeństwem w formie konkordatowej w rozumieniu przepisów polskiego prawa rodzinnego, natomiast małżeństwo obywateli polskich zawarte w Manilii przed polskim misjonarzem jednakże inkardynowanym w tamtejszej diecezji, będzie należało (po spełnieniu wymogów ustawodawstwa miejscowego) do małżeństw zawartych według lex loci celebrationis.

${ }^{37}$ Zgodnie z kan. $266 \S 1$ KPK przyjmujący diakonat staje się duchownym i zostaje inkardynowany do Kościoła partykularnego lub prałatury personalnej, dla posługi których został promowany, zaś w myśl kan. $268 \S 1$ KPK duchowny, który przesiedlił się zgodnie z przepisami prawa $\mathrm{z}$ własnego Kościoła partykularnego do innego, po upływie pięciu lat zostaje na mocy samego prawa inkardynowany do tego Kościoła partykularnego, jeśli taką wolę wyraził na piśmie zarówno biskupowi diecezjalnemu Kościoła goszczącego go, jak i własnemu biskupowi diecezjalnemu i żaden z nich nie wyraził na piśmie sprzeciwu w ciągu czterech miesięcy od otrzymania pisma. Od inkardynacji i ekskardynacji odróżnić należy opuszczenie przez duchownego własnej diecezji w celu pełnienia posługi w innym Kościele partykularnym, co może nastapić na skutek umowy zawartej pomiędzy biskupami a quo i a quem (zob. T. PAwLuK, Prawo kanoniczne wedtug Kodeksu Jana Pawła II, t. 2, Olsztyn 2002, s.78-79). Zgodnie z kan. 271 § 2 KPK biskup diecezjalny może zezwolić swoim duchownym na opuszczenie diecezji na czas określony, nawet wielokrotnie przedłużany, tak jednak, aby ci duchowni pozostali inkardynowani do własnego Kościoła partykularnego, a po powrocie cieszyli się wszystkimi uprawnieniami, jakie mieliby gdyby w nim wykonywali święte posługiwanie.

${ }^{38} \mathrm{~W}$ doktrynie kanonicznej przyjmuje się, iż inkardynacja nie jest tylko środkiem poddania duchownego biskupowi lecz inkorporacją do Kościoła partykularnego, przy czym nie jest to związek duchownego tylko ze strukturą terytorialną lecz również ze strukturami personalnymi (zob. J. KrUKowski, Komentarz do Rozdziału II Tytutu III, Księgi II, w: Komentarz do Kodeksu Prawa Kanonicznego. Tom II. Księga II Lud Boży, (red) J. Krukowski, Pallottinum 2005, s. 85). 


\section{Zawarcie małżeństwa w prawie prywatnym międzynarodowym według formy prawa ojczystego}

Teza, iż polscy katolicy mogą zawrzeć za granicą małżeństwo wyznaniowe przed inkardynowanym tam duchownym katolickim i małżeństwo tak zawarte, jeśli spełni wymogi prawa obowiązującego w miejscu jego zawarcia będzie wywoływało skutki w prawie polskim, wydaje się być tezą nie budzącą wątpliwości. Zagadnieniem o wiele bardziej złożonym i nastręczającym większych trudności interpretacyjnych jest natomiast odpowiedź na pytanie, czy obywatele polscy mogą zawrzeć za granicą małżeństwo wyznaniowe o skutkach cywilnych jednakże przed duchownym polskim tj. przed duchownym inkardynowanym w diecezji na terenie RP? A jeśli tak, to czy tego rodzaju możliwość zachodzi jedynie na terenie tych państw, które dopuszczają formę wyznaniową, czy również i tam, gdzie forma wyznaniowa nie jest przewidywana w ustawodawstwie miejscowym.

Prawo międzynarodowe prywatne poza omówioną wyżej, wynikającą $\mathrm{z}$ art. $15 \S 1$ p.p.m regułą lex loci celebrationis, w artykule 15 $\S 2$ p.p.m stanowi, iż w przypadku małżeństw zawieranych poza granicami Polski, wystarcza zachowanie formy wymaganej przez prawa ojczyste obojga małżonków. Sformułowanie ,wystarcza” wskazuje, iż znaczenie podstawowe ma zawsze prawo obowiązujące w miejscu zawarcia, jednakże dopuszczalna jest również forma prawa ojczystego, która ma wówczas charakter posiłkowy. Pomijając chwilowo rozważania dotyczące tego, co można uznać za „formę prawa ojczystego" $\mathrm{w}$ odniesieniu do regulacji przyjętych $\mathrm{w}$ prawie polskim, podkreślić należy, iż również w przypadku art. $15 \S 2$ p.p.m odpowiednie zastosowanie ma wspomniana wyżej reguła art. $1 \S 2$ p.p.m. Oznacza to, iż możliwość zastosowania zasady prawa ojczystego w odniesieniu do formy zawarcia małżeństwa dopuszczalna jest tylko wówczas, jeśli obowiązująca Polskę umowa dwustronna nie postanawia inaczej. Kwestia ta jest o tyle istotna, że $\mathrm{z}$ analizy wymienionych wyżej umów dwustronnych zdaje się wynikać, iż możliwość zastosowania przy zawieraniu małżeństwa formy prawa ojczystego nie jest dopuszczalna jeśli małżeństwo miałoby być zawarte w Austrii, Estonii, Finlandii, Ro- 
sji, Rumunii, byłej Czechosłowacji oraz na Biołorusi, Kubie, Litwie, Łotwie. W umowach zawartych z tymi państwami postanowiono bowiem, iż forma zawarcia małżeństwa podlega prawu tej Umawiającej się Strony, na terytorium której małżeństwo jest zawierane. Umowy te nie przewidują zatem dopuszczalności zastosowania zasady formy prawa ojczystego, zaś zważywszy na fakt, iż - jak wskazano wyżej - wymienione państwa na swoim terytorium nie przewidują możliwości zawarcia małżeństwa $\mathrm{w}$ formie wyznaniowej, w państwach tych obywatele polscy mogą zawrzeć związek małżeński jedynie w formie cywilnej, według prawa miejscowego. Do podobnych wniosków (aczkolwiek z nieco innych powodów) należałoby dojść również w odniesieniu do Bułgarii, Francji, byłej Jugosławii, Korei Północnej, Mongolii, Węgier i Wietnamu. W umowach zawartych z tymi państwami użyto bowiem sformułowania, iż forma zawarcia małżeństwa podlega prawu tej Umawiającej się Strony, przed której organem małżeństwo zostaje zawarte. Użycie sformułowania ,przed organem” zdaje się jednoznacznie wskazywać, iż chodzi tu o organ władzy (administracji) publicznej $^{39}$ a zatem, że na obszarze tych państw dopuszczalna jest wyłącznie miejscowa forma zawarcia małżeństwa i to jedynie cywilna.

Zupełnie inaczej natomiast należałoby potraktować te przypadki, gdy do zawarcia małżeństwa dochodzi na obszarze tego państwa, z którym Polskę nie łączą umowy bilateralne regulujące przedmiotową materię. W takiej sytuacji bowiem bezpośrednie zastosowanie mają reguły zawarte $\mathrm{w}$ prawie prywatnym międzynarodowym, $\mathrm{w}$ tym omawiana zasada art. $15 \S 2$ p.p.m. dopuszczająca możliwość posiłkowania się formą prawa ojczystego. To zaś uprawnia do wniosku, iż jeśli przyjąć, że formą prawa ojczystego dla obywateli polskich może być forma wyznaniowa zawarcia małżeństwa, to zgodnie z regułą art. $15 \S 2$ p.p.m, małżeństwo zawarte w tej formie wywoływałoby skutki w prawie polskim nawet gdyby do jego zawarcie doszło na obszarze państwa, które przewiduje wyłącznie formę cywilną. Odwołując się

${ }^{39} \mathrm{Na}$ okoliczność tę zwraca w swoich publikacjach uwagę K. PietrzyKowsKi, zob. Międzynarodowe aspekty ..., j.w, s. 276; tenże, Komentarz do art. 1 k.r.o., w: Kodeks rodzinny i opiekuńczy ..., j.w, s. 135-136. 
do konkretnego przykładu wskazać można, iż małżeństwo obywateli polskich zawarte według prawa ojczystego $\mathrm{w}$ formie wyznaniowej np. w Niemczech, Belgii czy Holandii byłoby na mocy art. $15 \S 2$ p.p.m skuteczne (przy dopełnieniu szczegółowych przesłanek wynikających $\mathrm{z}$ prawa polskiego) w polskim porządku prawnym. $\mathrm{Z}$ tych samych względów zasada ta miałby zastosowanie również tych państwach, z którymi nie łączą Polskę umowy dwustronne, a w których forma wyznaniowa jest dopuszczalna według prawa miejscowego. W takich krajach (np. Grecja, Hiszpania, Włochy) obywatele polscy mieliby możliwość zawarcia związku małżeńskiego w formie wyznaniowej według lex loci celebrationis lub według prawa ojczystego.

Przechodząc do kwestii dotyczącej pojęcia „forma prawa ojczystego" odnotować należy, iż formą tą dla obywateli polskich zamierzających zawrzeć związek małżeński za granica jest forma małżeństwa konsularnego tj. małżeństwa zawieranego przed polskim konsulem. Wskazuje na to treść art. $1 \S 4$ k.r.o., który mówi, iż mężczyzna i kobieta będący obywatelami polskimi przebywającymi za granica, mogą zawrzeć małżeństwo również przed konsulem lub przed osobą wyznaczoną do wykonywania funkcji konsula ${ }^{40}$. To, iż przepisy prawa rodzinnego wymieniają expressis verbis małżeństwo konsularne jako formę ojczystą dla obywateli polskich za granicą nie wydaje się być jednakże argumentem dowodzącym, iż jest to forma ojczysta jedyna. Skoro bowiem nie ulega wątpliwości, iż każdy Polak w swojej ojczyźnie ma prawo do zawarcia małżeństwa w formie konkordatowej określonej w art. $1 \S 2$ i 3 k.r.o., to stwierdzenie, iż ta forma nie jest formą prawa ojczystego obywateli polskich pozostawałoby w sprzeczności zarówno z polskim porządkiem prawnym jak i zasadami logicznego wnioskowania. Na marginesie zauważyć należy, iż pomiędzy małżeństwem zawartym w formie konkordatowej a małżeństwem zawartym przed konsulem istnieje szereg elementów upodabniających obie te

\footnotetext{
${ }^{40}$ Zaznaczyć jednakże należy, iż dopuszczalność zawarcia małżeństwa przed polskim konsulem za granicą jest uzależniona nie tylko od tego, czy odpowiednie uprawnienia w tym zakresie zostały konsulowi przyznane przez prawo polskie ale i od stanowiska państwa przyjmującego.
} 
formy do siebie ${ }^{41}$, łącznie $\mathrm{z}$ tym, iż obie odpowiadają art. 1 ust.1 Konwencji nowojorskiej ${ }^{42}$.

Zakładając zatem, iż małżeństwo w formie konkordatowej byłoby w przypadku jego zawierania za granicą małżeństwem w formie ojczystej, o której mowa w art. 15 ust. 2 p.p.m, koniecznym staje się rozważenie, czy małżeństwo tak zawarte odpowiadałoby wszystkim kryteriom szczegółowym przewidzianym w $§ 2$ art. 1 k.r.o., od spełnienia których zależy skuteczność tej czynności na gruncie prawa polskiego. Czy byłoby ono więc zgodne z prawem wewnętrznym Kościoła katolickiego, czy czyniłoby zadość wymogom art. 8 k.r.o. i czy możliwa byłaby jego rejestracja w polskim urzędzie stanu cywilnego?

\subsection{Małżeństwo na obczyźnie a prawo wewnętrzne Kościoła katolickiego}

Dopuszczalność zawarcia za granicą małżeństwa podlegającego prawu kanonicznemu wymaga analizy w dwóch zasadniczych płaszczyznach: tej, która odnosi się do osób tj. uprawnień i obowiązków wiernych i duchownego, oraz tej która odnosi się do rodzajów formy ${ }^{43}$.

W odniesieniu do kwestii dotyczącej osób stwierdzić należy, iż przepisy prawa kanonicznego nie przewidują normy, która uniemożliwiałaby wiernym zawarcie małżeństwa poza własną parafią i diecezją,

${ }^{41}$ Pogląd taki głosi m.in. R. A. DomaŃSKI, Konstytutywny czy deklaratywny charakter sporzadzenia aktu matżeństwa $w$ USC $w$ przypadku matżeństwa konkordatowego, Państwo i Prawo 2006, z. 3, s. 98.

${ }^{42}$ Art. 1 ust. 1 Konwencji w sprawie zgody na zawarcie małżeństwa, najniższego wieku małżeństwa i rejestracji małżeństwa, otwarta do podpisania w Nowym Yorku 10 grudnia 1962 r. (Dz.U. 1965, Nr 9, poz.53) przewiduje, że zgoda obu stron co do zawarcia małżeństwa powinna być wyrażona w obecności właściwej władzy, przy czym - jak wskazuje R. A. Domański (tamże, s. 98) - władzą tą jest zarówno konsul jak i duchowny w Kościele partykularnym.

${ }^{43}$ Do ważności małżeństwa kanonicznego Kodeks Prawa Kanonicznego wymaga również nieistnienia przeszkód pomiędzy nupturientami oraz brak wad zgody małżeńskiej. Według przeważających poglądów doktryny podstawę uzyskania skutków cywilnych stanowi małżeństwo zawarte w formie kanonicznej, niezależnie czy jest ono ważne czy nieważne w świetle prawa kanonicznego (zob. m.in. J. KRUKOwsKI, Konkordat polski-znaczenie i realizacja, Lublin 1999, s. 203). 
a tym samym poza granicami kraju. Kan.1115 KPK stanowi jedynie, iż małżeństwa winny być zawierane w parafii, gdzie przynajmniej jedno z nupturientów posiada stałe lub tymczasowe zamieszkanie ${ }^{44}$ lub miesięczny pobyt, przy czym za zezwoleniem własnego ordynariusza albo własnego proboszcza wolno małżeństwo zawrzeć w innym miejscu. Kan. 1118 § 1 KPK mówi zaś, iż małżeństwo pomiędzy katolikami winno być zawarte w kościele parafialnym jednakże może być zawarte i w innym kościele lub kaplicy za zezwoleniem ordynariusza miejsca lub proboszcza, a za zezwoleniem miejscowego ordynariusza nawet i w innym odpowiednim miejscu (kan.1118 § 2 KPK) ${ }^{45}$.

W odniesieniu natomiast do osób duchownych upoważnionych do przyjęcia oświadczeń o zawarciu małżeństwa ${ }^{46}$ wskazać należy, iż ordynariusz miejsca i proboszcz mogą ważnie asystować przy zawieraniu małżeństwa jednakże tylko w granicach własnego terytorium (kan.1109 KPK) i również jedynie w granicach własnego terytorium mogą delegować ogólne upoważnienie do asystowania przy zawieraniu małżeństw innym kapłanom i diakonom (kan. 1111 § 1 KPK). Zgodnie

\footnotetext{
${ }^{44}$ Kan. 102 § 1 KPK stanowi, iż: „Zamieszkanie stałe nabywa się takim przebywaniem na terytorium jakiejś parafii lub przynajmniej diecezji, które albo jest połączone z zamiarem pozostania tam na stałe, jeśli nic stamtąd nie odwoła, albo trwało przez pełnych pięć lat”; $\S 2$ : „Tymczasowe zamieszkanie nabywa się przez takie przebywanie na terenie jakiejś parafii lub przynajmniej diecezji, które albo jest połączone z zamiarem pozostania tam przynajmniej przez trzy miesiące, jeśli nic stamtąd nie odwoła, albo przedłużyło się rzeczywiście do trzech miesięcy".

${ }^{45} \mathrm{~W}$ przypadku gdy nupturienci zamierzają zawrzeć związek małżeński poza własną parafią i przed obcym duchownym winni uzyskać stosowną licencję lub zezwolenie. Licencja jest wystawiana przez proboszcza własnego stron (odpowiedzialnego za kanoniczne przygotowanie przedślubne i oraz wygłoszenie zapowiedzi) i jest potwierdzeniem, że pomiędzy stronami nie zachodzą przeszkody do zawarcia małżeństwa natomiast zezwolenie jest wystawiane przez ordynariusza miejsca lub proboszcza i stanowi upoważnienie dla obcego duchownego do dokonania wszystkich przedślubnych czynności. Zarówno licencja jak i zezwolenie wymagane są tylko do godziwości zawieranego związku małżeńskiego, nie zaś do jego ważności (zob. A. MezGLEwski, A. TuniA, Wyznaniowa forma zawarcia matżeństwa cywilnego, Warszawa 2007, s. 36). 46 Osoby te w literaturze kanonicznej są nazywane: świadkami urzędowymi, świadkami kwalifikowanymi, urzędowymi świadkami zwyczajnymi, kwalifikowanymi świadkami zwyczajnymi, delegowanymi świadkami zwyczajnymi.
} 
z wymienioną zasadą duchowni nie mogą zatem w oparciu o urząd lub delegację, które obowiązują na obszarze własnej parafii czy diecezji (lub jednostki prawnie z nią zrównanej), ważnie asystować przy małżeństwie zawieranym na innym terytorium. Brak przedmiotowego umocowania nie ma jednakże charakteru bezwzględnego. Przebywając bowiem na obszarze innej diecezji, w tymi diecezji położonej poza granicami kraju, duchowny może uzyskać władzę do asystowania przy zawieraniu małżeństwa na mocy prawa partykularnego tj. na skutek delegacji ogólnej lub specjalnej ${ }^{47}$ udzielonej przez miejscowego ordynariusza lub proboszcza (kan. $1111 \S 1$ i 2 KPK).

Podsumowując tę płaszczyznę analizy stwierdzić zatem należy, iż w zakresie wymogów odnoszących się do osób, w prawie wewnętrznym Kościoła katolickiego nie ma przeszkód, które nie pozwalałyby wiernym na zawarcie małżeństwa w formie kanonicznej za granicą jak również nie ma przeszkód, które w sposób kategoryczny uniemożliwiałyby osobom duchownym asystowanie przy zawieraniu małżeństwa poza obszarem własnej jurysdykcji, w tym poza granicami kraju, na obszarze którego są oni inkardynowani.

Osobną kwestią wymagająca pewnego wyjaśnienia jest to, kogo należy rozumieć pod pojęciem „osoba duchowna”. Kwestia ta wydaje się być dość oczywista w świetle prawa kanonicznego, jednakże bliższa analiza przepisów ustaw wyznaniowych, PrAsc oraz Kodeksu prawa rodzinnego i opiekuńczego ujawnia- jak trafnie wskazuje się w literaturze ${ }^{48}$ - zasadnicze wątpliwości. Nie wchodząc w głębie tego problemu zaznaczyć jedynie należy, iż zakres pojęcia „duchowny" używany w wymienionych aktach prawnych nie jest analogicz-

${ }^{47}$ Delegacja ogólna polega na upoważnieniu kapłana lub diakona do asystowania przy wszystkich małżeństwach, które mogą być zawierane w danej parafii lub diecezji, natomiast delegacja szczególna polega na upoważnieniu tych duchownych do asystowania przy zawieraniu tylko wyraźnie wskazanego małżeństwa. Delegacja ogólna winna być udzielona na piśmie, szczególna może być ustna (zob. J. RAPACz, Zwyczajna forma zawarcia małżeństwa wedtug kodeksu Jana Pawła II, PK 1998, Nr 1-2, s. 239-258).

${ }^{48}$ Problematykę tę porusza m.in. A. Mezglewski, A. Tunia (Wyznaniowa forma ..., j.w, s. 85-106). 
ny ${ }^{49}$, jednakże zważywszy na istotę omawianego zagadnienia dość powiedzieć, że w procesie zawierania małżeństwa cywilnego w formie wyznaniowej wyodrębnić można czynny udział dwóch duchownych o różnych zakresach kompetencji: tego, który jest kompetentny do asystowania przy zawarciu małżeństwa i tego, który jest uprawniony do sporządzenia zaświadczenia będącego podstawą cywilnej rejestracji małżeństwa. Duchownego kompetentnego do przyjęcia oświadczenia o zawarciu małżeństwa określa prawo wewnętrzne danego kościoła lub związku wyznaniowego, natomiast duchownego upoważnionego do sporządzenia zaświadczenia stanowiącego podstawę cywilnej rejestracji małżeństwa określają przepisy państwowe tj. ustawa $\operatorname{PrAsc}{ }^{50}$ oraz wydane w oparciu o zawartą tam delegację ustawową przepisy wykonawcze ${ }^{51}$.

Odnosząc tę uwagę do zagadnienia będącego przedmiotem rozważań w tej części niniejszej publikacji stwierdzić należy, iż w przypadku duchownego Kościoła katolickiego, który jednocześnie spełniałby oba wskazane wyżej wymogi tj. byłby osobą uprawnioną zarówno do przyjęcia oświadczenia o zawarciu małżeństwa jak i do sporządzenia zaświadczenia służącego cywilnej rejestracji tego małżeństwa (co w praktyce wydaje się być zjawiskiem najczęstszym) brak jest podstaw do uznania, iż istnieja jakiekolwiek przeszkody natury prawnej (w porządku prawa kanonicznego i polskiego), które uniemożliwiały-

\footnotetext{
${ }^{49}$ Zagadnienie to A. Mezglewski szerzej rozwija również w publikacji: Pojęcie „duchownego” w przepisach prawa polskiego o zawieraniu matżeństwa (Studia z Prawa Wyznaniowego, t. 2, Lublin 2001, s. 5-25).

${ }^{50}$ Art. 27 ust. 2 PrAsc stanowi, iż minister właściwy do spraw wewnętrznych, na podstawie informacji otrzymanych od właściwych przedstawicieli kościołów i innych związków wyznaniowych, ogłasza w „Monitorze Polskim” obwieszczenie zawierające wykaz stanowisk, których zajmowanie upoważnia do sporządzenia zaświadczenia stanowiącego podstawę do sporządzenia aktu małżeństwa zawartego w sposób określony w art. 1 § 2 i 3 k.r.o., zaś osoba zajmująca jedno z tych stanowisk jest duchownym w rozumieniu przepisów o zawarciu małżeństwa.

${ }^{51}$ Zgodnie z Obwieszczeniem Ministra Spraw Wewnętrznych i Administracji z dnia 21 lutego 2008 r. (M.P. Nr 18, poz. 19) w przypadku Kościoła katolickiego osobami tymi są: ordynariusz miejsca, proboszcz, administrator parafii, wikariusz w zastępstwie proboszcza, duchowny w zastępstwie proboszcza.
} 
by tym osobom duchownym udział w czynnościach zawarcia małżeństwa w omawianej formie konkordatowej za granicą.

Przechodząc natomiast do płaszczyzny dotyczącej rodzajów formy kanonicznej przede wszystkim zaznaczyć trzeba, iż wszystkie uwagi poczynione powyżej dotyczą zwyczajnej formy kanonicznej tj. formy określonej w kan. 1108 KPK, który stanowi, iż małżeństwo zawierane jest wobec asystującego miejscowego ordynariusza albo proboszcza albo wobec kapłana lub diakona delegowanego przez jednego z nich, a także wobec dwóch świadków. Przepisy prawa kanonicznego dopuszczają jednakże możliwość zawarcia małżeństwa kanonicznego również według formy nadzwyczajnej, określonej w kan. 1116 KPK. Zgodnie z tym kanonem możliwość zawarcia małżeństwa w formie nadzwyczajnej istnieje w dwóch zasadniczych wariantach: a) w niebezpieczeństwie śmierci - z udziałem duchownego nieposiadającego jurysdykcji lub bez udziału duchownego; b) w sytuacji gdy osoba kompetentna do asystowania przy zawarciu małżeństwa jest nieosiagalna lub nie można się do niej udać bez poważnej niedogodności, jeśli roztropnie się przewiduje, że niedogodność ta będzie trwała przez miesiąc - z udziałem duchownego nieposiadającego jurysdykcji lub bez udziału duchownego. Abstrahując od szczegółowych rozważań, czy za małżeństwa kanoniczne w rozumieniu Konkordatu ${ }^{52}$ uznać należy jedynie małżeństwa zawarte $\mathrm{w}$ formie zwyczajnej czy też również $\mathrm{i}$ te zawarte na podstawie kan.1116 KPK zgodzić należy się z generalną tezą, iż skutki cywilne uzyskać może zarówno małżeństwo zawarte według formy zwyczajnej jak i według formy nadzwyczajnej, o ile zawarte zostały w obecności duchownego, który może nadać bieg procedurze jego cywilnej rejestracji ${ }^{53}$. Wydaje się przy tym, iż wbrew pewnym

${ }^{52}$ Konkordat między Stolicą Apostolską i Rzeczpospolitą Polską podpisany w dniu 28 lipca 1993 r. (Dz.U. z 1993, Nr 51, poz. 318).

${ }^{53}$ Pogląd ten prezentują m.in.: J. KRUKOWsKI, Zawarcie matżeństwa kanonicznego ze skutkami ze skutkami cywilnymi [art.10 konkordatu między Stolica Apostolska a Rzeczpospolita Polska], Roczniki Nauk Prawnych, t. 9, Prawo, z. 1, s. 226-227; A. Mezglewski, Przepisy wprowadzajace $w$ życie instytucję matżeństwa konkordatowego, Roczniki Nauk Prawnych, t. 9, Prawo, z. 1, s. 247-251; M. NAzAR, Zawarcie matzeństwa wedtug prawa polskiego uwzględnieniem postanowień podpisanego 
wattpliwościom podnoszonym $\mathrm{w}$ literaturze ${ }^{54}$ pogląd ten $\mathrm{w}$ jednakowym stopniu winien odnosić się zarówno do przypadku określonego w pkt. a jak i pkt.b tj. do sytuacji dotyczącej niebezpieczeństwa śmierci jak i do sytuacji braku osoby kompetentnej do asystowania. Wprawdzie jedynie przypadek określony w pkt. a koresponduje z art. $9 \S 2$ k.r.o., jednakże w obowiązujących przepisach prawa polskiego trudno doszukać się regulacji, która wyłączałaby sytuację określoną w pkt. b spod hipotezy art. $1 \S 2$ k.r.o. (o ile nupturienci dopełniliby wymogu przedstawienia zaświadczenia o braku okoliczności wyłączających zawarcie małżeństwa). Podkreślić bowiem należy, iż wymieniony przepis odwołuje się do prawa wewnętrznego Kościoła katolickiego a ono, jak wskazano wyżej, dopuszcza możliwość zawarcia małżeństwa w formie nadzwyczajnej w obu wymienionych wariantach. Zauważyć też należy, iż zawarty w obwieszczeniu MSWiA wykaz stanowisk, których zajmowanie uprawnia do sporządzenia zaświadczenia o zawartym małżeństwie, mówiąc o upoważnieniu jakie w tym względzie proboszcz może udzielić innemu duchownemu, ani nie określa sposobu udzielenia tego upoważnienia ani nie zawiera w tym zakresie żadnych dodatkowych ograniczeń. Wydaje się zatem, że osoba duchowna zajmująca stanowisko wymienione w omawianym obwieszczeniu lub mająca tego rodzaju upoważnienie skutecznie udzielone przez proboszcza we własnej parafii w kraju, jest osobą uprawnioną do sporządzenia zaświadczenia o zawartym małżeństwie również przebywając poza granicami RP.

Mówiąc o formach kanonicznych zawarcia małżeństwa nadmienić również trzeba, iż prawo wewnętrzne Kościoła katolickiego dopuszcza też i takie sytuacje, w których może nastąpić zwolnienie (dyspensa) od formy kanonicznej ${ }^{55}$. Nie rozwijając tego nader złożonego za-

28 lipca 1993 r. konkordatu między Stolica Apostolskq i Rzeczpospolita Polska, Kwartalnik Prawa Prywatnego 1996, Nr 3, s. 447-509.

${ }^{54}$ A. Mezglewski, A. Tunia, Wyznaniowa forma ..., j.w., s. 40.

${ }^{55}$ Władza udzielenia dyspensy od formy kanonicznej przysługuje z mocy prawa Stolicy Apostolskiej. Przysługuje ona również ordynariuszowi miejsca w sytuacji niebezpieczeństwa śmierci, zawierania małżeństw mieszanych oraz w ramach tzw. uważnienia małżeństwa w zawiązku (kan. 1079 § 1, kan. 1127 § 2, kan. 1165 § KPK). W przypadku braku możliwości odniesienia się do ordynariusza miejsca prawo do udzielenia dyspensy w niebezpieczeństwie śmierci przysługuje również proboszczo- 
gadnienia dość powiedzieć, iż w tych przypadkach, gdy małżeństwo na skutek dyspensy zawierane byłoby bez obecności duchownego, małżeństwo tak zawarte nie mogłoby wywołać skutków w polskim prawie cywilnym wobec nie spełnienia jednego z podstawowych wymogów określonych w art. $1 \S 2$ k.r.o. W przypadku natomiast gdyby na skutek dyspensy było zawarte za granicą w obecności duchownego innego wyznania chrześcijańskiego, będącego jednocześnie duchownym wymienionym w wykazie stanowisk MSWiA wydaje się, iż tego rodzaju skutku wykluczyć nie można ${ }^{56}$, aczkolwiek watpliwość może budzić to, czy tego rodzaju formę (będącą swoistą hybrydą praw wewnętrznych różnych kościołów) można byłoby uznać za „formę ojczystą” w rozumieniu wspomnianego wyżej art. 15 ust. 2 p.p.m.

Reasumując, w świetle przepisów prawa kanonicznego odnoszących się do formy zawarcia małżeństwa nie ma przeszkód, które uniemożliwiałyby wiernym mającym obywatelstwo polskie, zawarcie małżeństwa za granicą przed osobą duchowną inkardynowaną w diecezji polskiej. Po spełnieniu wskazanych wyżej warunków - specyficznych dla formy zwyczajnej i nadzwyczajnej - nic nie stoi na przeszkodzie, by małżeństwo zawarte w tego rodzaju układzie sytuacyjnym uznać za małżeństwo podlegające wewnętrznemu prawu Kościoła katolickiego, W rozumieniu art. $1 \S 2$ k.r.o.

\subsection{Małżeństwo przed polskim duchownym za granicą} a wymogi art. 8 k.r.o.

Zgodnie z art. $8 \S 1$ k.r.o. duchowny nie może (za wyjątkiem małżeństwa in articulo mortis) przyjąć od nupturientów oświadczeń woli jednoczesnego zawarcia małżeństwa podlegającego prawu polskiemu

wi, kapłanowi i diakonowi delegowanemu do asystowania przy zawieraniu małżeństwa (kan. 1079 § 2 KPK). Możliwość udzielenia dyspensy od formy kanonicznej prawodawca kościelny uzależnia od istnienia słusznej i rozumnej przyczyny (zob. W. GóRALski, Dyspensa od formy zawarcia matżeństwa w świetle nowego kodeksu prawa kanonicznego, PK 1988, Nr 1-2, s. 90-92.

${ }^{56}$ Stanowisko takie prezentują A. Mezglewski i A. Tunia, Wyznaniowa forma ..., j.w., s. 44. Autorzy ci wskazuja, iż w takim przypadku duchowny ten mógłby nadać bieg procedurze rejestracyjnej ,w swoim imieniu”. 
bez uprzedniego przedstawienia mu zaświadczenia sporządzonego przez kierownika USC stwierdzającego brak okoliczności wyłączających zawarcie małżeństwa ${ }^{57}$. Zaświadczenie to jest wydawane przez kierownika USC właściwego ze względu na miejsce zamieszkania jednej z osób zamierzających zawrzeć małżeństwo w sposób określony w art. $1 \S 2$ k.r.o. Powyższa zasada wskazująca na właściwość kierownika USC odnosi się również do tych osób, które mieszkają za granicą i tam zamierzają zawrzeć związek małżeński, na co wskazuje jednoznaczna treść art. 71 ust. 1 i 2 PrAsc. Wyjątek od tej zasady dotyczy jedynie tych obywateli polskich zamieszkałych za granica, którzy albo nie mieli miejsca zamieszkania w Polsce albo nie można ustalić ich ostatniego miejsca zamieszkania w Polsce bądź wyjechali z Polski przed ukończeniem 16 roku życia i stale przybywają za granica. $\mathrm{W}$ takich przypadkach, w myśl art. 71 ust. 3 PrAsc wymienione zaświadczenia wystawia konsul.

Zagadnieniem mogącym budzić większe trudności interpretacyjne jest to, jak w praktyce miałaby wyglądać realizacja wymogów określonych $\mathrm{w} \S 2 \mathrm{i} 3$ art. 8 k.r.o. Zgodnie bowiem z procedurą przewidzianą w tych przepisach, niezwłocznie po złożeniu oświadczeń o woli jednoczesnego zawarcia małżeństwa podlegającego prawu polskiemu, duchowny ${ }^{58}$ obowiązany jest sporządzić zaświadczenie stwierdzające fakt złożenia wymienionych oświadczeń (oraz fakt zawarcia małżeństwa podlegającego prawu wewnętrznemu Kościoła katolickiego) i następnie, przed upływem pięciu dni winien je przekazać do urzędu stanu cywilnego. Zaświadczenie to, zgodnie z art. 61a PrAsc, stanowi podstawę sporządzenia aktu małżeństwa zawartego w sposób określony

${ }^{57}$ Wniosek ten wynika expressis verbis z brzmienia art. $8 \S 1$ k.r.o. R. Sobański uważa jednakże, iż przedłożenie zaświadczenia (podobnie jak i jego ważność) nie należą do elementów konstytutywnych zdarzenia prawnego, którego skutkiem jest powstanie cywilnoprawnego stosunku małżeńskiego a racje zakazu czynności nie są tożsame z racjami pozbawienia czynności skuteczności (zob. tenże, Zaświadczenie urzędu stanu cywilnego a przesłanki małżeństwa , konkordatowego”, Państwo i Prawo 2003, z. 5, s. 32).

${ }^{58}$ Jak wskazano wyżej, chodzi tu o duchownego określonego w art. 27 ust. 2 PrAsc a nie duchownego asystującego przy zawarciu małżeństwa. 
w art. $1 \S 2$ i 3 k.r.o. Abstrahując od istniejących w literaturze sporów co do charakteru terminu pięciodniowego ${ }^{59}$ jak również co do tego, czy sporządzenie aktu małżeństwa ma charakter konstytutywny ${ }^{60}$ czy deklaratywny ${ }^{61}$ zauważyć należy, iż dopełnienie tych formalności za granicą z oczywistych względów może być problematyczne. W przypadku owego terminu pięciodniowego ustawodawca wprawdzie nieco „złagodził" reżim czasowy nie wliczając do biegu tego terminu dni ustawowo wolnych od pracy ${ }^{62}$ oraz uznając, iż nadanie wspomnianego zaświadczenia jako przesyłki poleconej w polskiej placówce pocztowej operatora publicznego jest równoznaczne z przekazaniem go do urzędu stanu cywilnego jednakże trudno regułę tę stosować w warunkach państwa obcego, w których polskich placówek pocztowych nie ma. Dochowanie zatem wspomnianego terminu w sytuacji gdy małżeństwo zawierane jest poza granicami Polski niewatpliwe byłoby utrudnione, jednakże nie oznacza to, że jest niemożliwe. W tym aspekcie przede wszystkim zwrócić należy uwagę, iż zgodnie z „Instrukcją Konferencji Episkopatu Polski dla duszpasterzy" z 22 października 1998 r. ${ }^{63}$ poruszająca zagadnienie dotyczące sposobu przekazania zaświadczenia do urzędu stanu cywilnego, duchowny może sporządzone przez siebie zaświadczenie przekazać m.in. za pośrednictwem posłańca. W literaturze trafnie też podnosi się, iż jakkolwiek z przeważającej opinii doktryny oraz ukształtowanej praktyki wynika, że jedynym

${ }^{59}$ M. Szczyrba, Charakter prawny 5-dniowego terminu z art. 8 \& Kodeksu rodzinnego i opiekuńczego, Gdańskie Studia Prawnicze 2003, t. 10, s. 590-595.

${ }^{60}$ Za taką tezą opowiada się m.in. T. SMYCZYŃski, Nowelizacja prawa matżeńskiego, Państwo i Prawo 1999, Nr 1, s. 26; tenże Konstytutywny charakter sporzqdzenia aktu małżeństwa konkordatowego. Dwugłos, Państwo i Prawo 2006, Nr 3, s. 100.

${ }^{61}$ Zwolennikiem tej koncepcji są m.in.: A. MĄCZYŃSKI, Znaczenie prawne aktu matżeństwa $w$ świetle kodeksu rodzinnego i opiekuńczego oraz prawa o aktach stanu cywilnego. Valeat aeqiutas. Księga pamiątkowa ofiarowana Księdzu Profesorowi Remigiuszowi Sobańskiemu, Katowice 2000, s. 317; K. PietrzyKowski, Komentarz do art. 1 k.r.o., w: Komentarz do Kodeksu rodzinnego ...,j.w, s. 125-126.

${ }^{62}$ Wynika to z art. $8 \S 3$ k.r.o w brzmieniu nadanym ustawą z 6 listopada 2008 r. o zmianie ustawy Kodeks rodzinny i opiekuńczy oraz niektórych innych ustaw (Dz.U. z 2008, Nr 220, poz. 1431).

${ }^{63}$ Biuletyn KAI z 17 listopada 1998 r., Nr 9, s. 15-18. 
podmiotem uprawnionym do przekazania (w formie pośredniej lub bezpośredniej) wspomnianego zaświadczenia do USC jest duchowny, to jednakże wniosku o wyłącznej kompetencji duchownego nie można wysnuć w sposób kategoryczny z brzmienia obowiązujących przepisów. Autorzy stawiający tę tezę uznają, iż tego rodzaju uprawnienie przysługuje również i samym małżonkom, którzy umocowanie to czerpią z art. 28 k.p.a. ${ }^{64}$ Co ciekawe przy tym, w świetle prezentowanego poglądu termin pięciodniowy wiąże jedynie duchownego, natomiast złożenie przez małżonków wniosku o rejestrację małżeństwa nie jest związane żadnym terminem ${ }^{65}$.

Kolejną kwestią mogącą rodzić wątpliwości co do realizacji procedury rejestracyjnej małżeństwa zawartego $\mathrm{w}$ omawianym układzie sytuacyjnym jest to, do jakiego urzędu stanu cywilnego należałoby wspomniane zaświadczenie skierować, a zatem, kierownik jakiego USC byłby właściwy - w myśl art. $1 \S 2$ k.r.o. - do sporządzenia aktu małżeństwa. Problem ten wynika z wyrażonej w art. 12 § 3 PrAsc zasady, która głosi, iż akt małżeństwa zawartego w sposób określony w art. $1 \S 2$ i 3 k.r.o. sporządza się w urzędzie stanu cywilnego właściwego ze względu na miejsce zawarcia małżeństwa. $Z$ oczywistych względów wymogu tego nie sposób dochować poza terytorium RP, jednakże - jak wydaje się -nie jest to problem nie do pokonania. Rozważając omawiane zagadnienie $\mathrm{w}$ optyce zasady in faworem matrimonii zauważyć bowiem należy, iż art. 70 PrAsc dopuszcza możliwość zarejestrowania w polskich księgach stanu cywilnego małżeństwa zawartego za granicą jeżeli nie zostało ono zarejestrowane w zagranicznych księgach stanu cywilnego. Z art. 13 i 15 PrAsc wynika zaś, że zarejestrowanie zawarcia małżeństwa które nastąiło za granicą dokonuje się w urzędzie stanu cywilnego miejsca zamieszkania wnioskodawcy. Jeżeli

${ }^{64}$ Pogląd ten prezentują: A. Mezglewski, A. Tunia, Wyznaniowa forma ..., j.w., s. 181-184. Wskazany przepis dotyczy ustawy z dnia 14 czerwca 1960 r. Kodeks postępowania administracyjnego (Dz.U. z 1960, Nr 9, poz.26 z późn. zm).

${ }^{65}$ Oznacza to, że jeżeli wniosek małżonków złożony zostanie po upływie terminu pięciodniowego, rejestracja małżeństwa nastąpi pod warunkiem, że wnioskodawcy nadal są stanu wolnego oraz że nie naruszają w ten sposób słusznie nabytych praw osób trzecich (tamże, s. 193). 
wnioskodawca nie ma miejsca zamieszkania w kraju - w urzędzie stanu cywilnego ostatniego miejsca zamieszkania w kraju, a w braku takiej podstawy - w Urzędzie Stanu Cywilnego m.st. Warszawy. Zaznaczyć przy tym należy, iż art. 70 PrAsc nie normuje, kto może być wnioskodawcą w sprawie uregulowanej tym przepisem ${ }^{66}$. Przyjmując, iż wymienione urzędy stanu cywilnego byłyby właściwe miejscowo do dokonania rejestracji małżeństwa zawartego w omawianej sytuacji jednocześnie należałoby stwierdzić, iż racje wskazane wyżej przemawiają równocześnie za tym, by kierowników tychże urzędów uznać za właściwych do sporządzenia aktów małżeństwa w trybie art. 61a PrAsc.

Z powyższego wynika zatem, iż jakkolwiek dopełnienie wymogów określonych w art. 8 § 23 k.r.o., jak również określonego w art. 1 2 k.r.o. wymogu sporządzenia aktu małżeństwa, napotyka - w przypadku małżeństw zawieranych poza granicami kraju w omawianym kontekście sytuacyjnym - na problemy natury techniczno-wykonawczej, to jednakże problemy te nie są nie do pokonania. Nie wykluczają one możliwości dopełnienia wymogów rejestracji małżeństwa tak zawartego, zgodnie z procedura prawa polskiego.

Również ta płaszczyzna analiz wskazuje więc, iż zawarcie za granicą małżeństwa wyznaniowego przez obywateli polskich przed duchownym polskim może - przy spełnieniu warunków z art. 15 ust. 2 p.p.m oraz art. $1 \S 2$ k.r.o. i art. 8 k.r.o. - wywoływać skutki przewidziane przepisami prawa polskiego.

\section{Podsumowanie}

Pytanie dotyczące możliwości zawarcia za granicą małżeństwa wyznaniowego podlegającego prawu polskiemu jest pytaniem, na które nie sposób udzielić odpowiedzi jednej i uniwersalnej. Zważywszy na fakt, iż obywatele polscy rozsiani są po całym świecie szczegółowa analiza każdego z możliwych wariantów faktyczno-prawnych z oczywistych względów wykraczałaby zarówno poza ramy, jak i cel niniejszej publikacji.

${ }^{66}$ A. Czajkowska, E. Pachniewska, Prawo o aktach ...,j.w., s. 211. 
Abstrahując zatem od konkretnych rozstrzygnięć w odniesieniu do poszczególnych państw, przede wszystkim stwierdzić należy, iż przepisy prawa prywatnego międzynarodowego, prawa polskiego i prawa kanonicznego wskazują, iż małżeństwo obywateli polskich zawarte w kraju, w którym zawarcie małżeństwa w formie wyznaniowej jest prawnie dopuszczalne, przed osobą duchowną Kościoła rzymskokatolickiego inkardynowaną na obszarze tego kraju, będzie skuteczne w prawie polskim, o ile zachowane zostaną wszystkie wymogi formalne obowiązujące w miejscu jego zawarcia. Tego rodzaju możliwość wynikać może bądź to $\mathrm{z}$ określonej $\mathrm{w}$ art. $15 \S 1$ p.p.m. zasady lex loci celebrationis bądź z wiążących Polskę umów bilateralnych.

Analiza wspomnianych przepisów prawa prywatnego międzynarodowego, prawa polskiego i prawa kanonicznego, wskazuje również, iż w przedmiotowych regulacjach nie istnieją normy tego rodzaju, które wykluczałyby - co do zasady- możliwość zawarcia przez obywateli polskich związku małżeńskiego za granicą przed duchownym inkardynowanym w Polsce. Małżeństwo tak zawarte można bowiem uznać za małżeństwo odpowiadające wymogom art. $1 \S 2$ i 3 k.r.o., a tym samym za małżeństwo zawarte $\mathrm{w}$ formie prawa ojczystego o którym mowa w art. $15 \S 2$ p.p.m. Dopełnienie wymogów rejestracji tak zawartego małżeństwa w polskim urzędzie stanu cywilnego (art. 8 k.r.o.) oraz sporządzenie aktu małżeństwa wiąże się z pewnymi trudnościami o charakterze organizacyjno-technicznym, jednakże nie jest niewykonalne. Możliwość zawarcia, w omawianym układzie sytuacyjnym, małżeństwa wywołującego skutki w prawie polskim, nie istnieje jedynie na obszarze tych państw, w których dopuszczalność posiłkowego zastosowania formy prawa ojczystego zastała wyłączona w umowach dwustronnych. Wszędzie tam natomiast, gdzie owe umowy dwustronne nie istnieją lub nie zawierają wspomnianych ograniczeń, zawarcie małżeństwa $\mathrm{w}$ formie wyznaniowej przed duchownym polskim podlega prawu polskiemu i jest dopuszczalne nawet wówczas, jeśli przepisy prawa miejscowego przewidują wyłącznie formę cywilną.

Z powyższego wynika, iż możliwość zawarcia przez obywateli polskich za granicą małżeństwa wyznaniowego, wywołującego skutki 
w prawie polskim jest stosunkowo szeroka. Okoliczność ta może stanowić pewną alternatywę zwłaszcza dla tych wiernych, którzy zawarcie sakramentalnego związku odkładają na bliżej nie sprecyzowany czas powrotu do kraju.

\section{Civil effects of canonical marriage contracted by Polish citizens before a clergyman of Roman Catholic Church abroad}

The subject matter of this publication is providing the answer to the question whether Polish citizens have abroad the ability to contract marriage in canonical form (before a clergyman of Roman Catholic Church) which would be governed by Polish law. With regard to the complexity of problematic nature of the issue, the answer cannot be universal. It should be stated, however, that this kind of ability is not excluded by private international law rules, Polish law and canon law. A marriage of Polish citizens contracted in a country in which contracting marriage in canonical form is legally permitted, before a clergyman of Roman Catholic Church incardinated within territory of that country, will take effect in Polish law providing that all formalities required in the place of contraction are retained. This ability eventuates either from the lex loci celebrationis rule applied in private international law or bilateral agreements binding on Poland. There are also no such norms in rules at issue that would exclude the ability to contract marriage by Polish citizens abroad before a clergyman incardinated in Poland. A marriage contracted in such manner can be thereby recognized as marriage satisfying requirements from Article 1(2) and 1(3) of Family and Guardianship Code; and by this means as marriage contracted in the form of national law, as set out in Article 15(2) of private international law. Completion of registration requirements for the so-called marriage in a Polish registry office and drawing up marriage certificate involve certain difficulties of organizational and technical nature. It is not, nevertheless, infeasible. Within this situational scheme, the ability to contract marriage that would have legal force in Polish law does not exist solely on territory of countries in which acceptability of ancillary application of national law form has been excluded in bilateral agreements. Conversely, in all places where the said bilateral agreements are not applicable or do not include the mentioned limitations, contracting marriage in the canonical form before a Polish clergyman is subject to Polish law and is permissible even if the domestic law regulations provide only for the civil form. 